Becoming a Legend:

Edna O'Brien and Her Life-Long Journey

\author{
ZUZANNA ZAREBSKA \\ University of Lisbon and ULICES, Portugal
}

\begin{abstract}
The publication of Germaine Greer's The Change: Women, Aging and the Menopause presents a manifesto for women's emancipation and their imminent embarkment on the avenue of freedom towards the liberation from the male gaze. In a similar vein, Edna O'Brien, a pioneer of the literary treatment of female agency and sexuality in the Irish literary canon, moves past the age when women enjoy visibility. Age liberates O'Brien from her entrapment in the public persona and her anxious relationship with the public opinion. It has the power to enhance the possibility of women's difference. Nowadays, the commitment to women's cause, the inherent element of O'Brien's narratives, continues to mark out the uncompromising discourse of transgression of the standard as well as her vigilant condemnation of violence against women. In time, O'Brien has become both a foremother author and a legend. She has embraced her unrepressed femininity and the personification of a female sage that Irish women writers have long lacked and may thus represent a role model for authors who wish to transgress the discriminatory standards and defend the female voice.
\end{abstract}

Keywords: Edna O'Brien, ageing, women, canon, public, private, fiction, Reifungsroman, discourse, violence

In October 1970, Germaine Greer announced in The Female Eunuch that women should give up celibacy and monogamy and embark on an avenue of freedom out of captivity. Greer ascribed to the female body a transcending capacity as it could wrench women from obligatory constraints of marriage, the society and the family. Her message for them was to abandon the deeply entrenched misogyny, reclaim the female soul, the right to education and voice. In 1993, Greer published yet another 
controversial work, The Change: Women, Aging and the Menopause, claiming that the extraordinary phase of being a woman - the menopause - could be her avenue of freedom towards what had been lost of the manifestos in The Female Eunuch.

It was precisely in the 1970s that Edna O'Brien had her photograph taken by a famous German photographer, Horst Tappe, later donated to The National Portrait Gallery by Terence Pepper in 2013. The photograph shows O'Brien as pensive, confident in her natural yet simple beauty. Such an embodied persona, empowered by assumed sexuality, rendered her the centre of public attention and ferocious criticism. She was now deemed a secondary gendered writer of popular fiction for women. Since O'Brien would not side or spar with any of the critical voices, she became entrapped in her own mannerism. To many she was merely an imposing public figure, a pop starlet with "flame red hair, milky skin and mesmerizing green flecked eyes" (Pattison 8). Her self-projected image triggered much disapproval as a prototype of a new Irish girl in a country controlled by traditionalists and the Catholic Church. Because of O'Brien's eccentricity and occasional pretension, the content and deeper meaning of her fiction were virtually unnoticed and overshadowed by what readers and critics saw on TV. In fact, O'Brien went as far as advertising shampoo in the 1970s and appearing on TV chat programs. Furthermore, her treatment of academics and of the prevailing ethos of literary criticism was defensive, especially when the reviewers would continuously pay more attention to the Irish act or a pub Irish persona. For instance, Peggy O'Brien in the Massachusetts Review (1987) compared Edna O'Brien to "an outrageous concoction of what foreigners expect an Irish person to be: mellifluous, volatile, wanton" (qtd. in Pelan, "Edna O’Brien's 'Stage-Irish' Persona” 67). Sometime later, however, when interviewed by Dawn Duncan for the Radio Times, O'Brien said, 'I'm a serious writer. Take more notice of the books than how I look. There's a notion that if one is photogenic, to put it jokingly, one is not serious" (Duncan 26).

In fact, there were many others, who saw in O'Brien a timewithstanding author of great courage. Seamus Heaney (1995) posited her as a pillar of the Irish literary canon, whereas Clare Boylan argued that 
O'Brien was one of the pioneers in introducing a theme of female desire, along with Margaret Atwood, Fay Weldon, Angela Carter and Marilyn French. She was a pioneer not only because of her literary treatment of sexuality but also because she was now moving past age 40 and coming into her own. She once admitted that the solitary spells during the writer's life were a necessary condition for better flourishing as an artist. The statement must have come as a shock to those who saw her exclusively as a public persona. Steering gradually away from the entrapment in the public image, O'Brien would point her attention towards the social interests of feminism, issues she initially addressed indirectly, eventually devoting her work to violence against women. She was interested in violence by which "the female speaking subject has been excluded from philosophy/discourse/culture," and ways for "work[ing] out the conditions for her accession to speech and social existence" (Whitford 137).

O'Brien came to the fore in the early 1960s, quickly gaining notoriety among critics for her publication of The Country Girls and The Lonely Girls (later published by Penguin as Girl with Green Eyes) displaying "fresh and unselfconscious charm [...] acute observation of life and fine, ribald sense of tone" (Pelan, "Reflections" 19). However, with the coming out of Girls in Their Married Bliss, August Is a Wicked Month and Causalities of Peace, the reviews plummeted with "critics left to wonder if they were assessing the same author, they had praised just six years earlier" (20). Apart from the tone, the latter three novels foreground an alternating, somewhat bitter narration instead of a sensitive and lyrical single narrator. For its supposed neo-feminist propaganda and a coarse and truthful representation of life, the Girls in Their Married Bliss was published in the United States in 1967, a year after the publication of Causalities of Peace and August Is a Wicked Month. The years until the early 1970s, that witnessed the appearance of A Pagan Place (1970) and Night (1972), divided critical attention to the quality of O'Brien's oeuvre, which was not easy to classify because of the lack of consistency and homogeneity that "high-brow" fiction by a single author would require. As a result, and as early as 1965, critical attention turned to O'Brien as a public gendered figure in a depreciating tone in the New York Times: 
Edna O'Brien came on like a brass band with cymbals clanging. And she did it speaking in a soft, sweet Irish brogue and looking like a cousin in from the country. It was hard to believe that this was the young woman who slathered those four-lettered Anglo-Saxon words all over the latest novel, about the sex-wild woman. (Pelan, "Reflections" 21)

Though O'Brien makes little of her looks in her memoir, A Country Girl (2012), she was a well-known beauty at the centre of swinging London in the 1960s and her glamour and fame became a part of her identity as a writer. If O'Brien's fiction was miscomprehended by the majority of the biased readership, her appearance drew much attention:

The skin was peaches and cream [O'Brien's], and the blue eyes were very clean, guileless, at once mirrors to the viewer, yet windows opening into a serious, intelligent mind. The hair, a red-gold mane, was pinned up on each side of her head. Looking like a schoolgirl in green little heel Mary Janes and a high-waisted, tight collar flowered print, the author of August is a Wicked Month [...] gestured with long-fingered hands to underscore her point. ("Reflections" 21)

However, O'Brien wanted to write for the sake of literature and language. Did she predict that her novels would draw so much attention and deteriorate her relationship with the reading public, the Church and her own family? Should she have known her fiction would be burnt and called "filth," she might never have had the courage to write. In fact, she says that she "wasn't at all conscious" of breaking the social and sexual barriers (qtd. in Murray). She was not at all conscious of following the blueprint, established in 1922 with the publication of James Joyce's Ulysses, of cosmopolitan, sexualized and anti-extremist Ireland. In O'Brien's words, “what Joyce did was revolutionary. He broke language as he determined and he remade it in a new and newly minted way. $\mathrm{He}$ gave it a magic urgency" (qtd. in Moreton). To continue the tradition of change, O'Brien's books were prohibited and burned around Ireland.

Apart from forging for herself a label as a revolutionary and as someone exposed to society's whimsical desire to gorge on the private lives of artists, O'Brien, deliberately or not, has always provoked public controversy. The readers could never understand whether the real O'Brien was performing the O'Brien everybody wanted to applaud or hate. Yet 
what O'Brien did say about the emotions she was experiencing in those days was that she always felt "extremely fearful and ashamed" (qtd. in Murray), even though she was "glad she wrote that story" (qtd. in Horgan). Whilst the Irish society saw her as a shocking woman writer or a sinful mother and a defying wife, she continued to write in exile for "everybody and nobody because it was her duty to write about the difficult themes" (qtd. in Murray). It is true that history is full of writers who traded genius for the limelight and madness. However, O'Brien's most recent novels dedicated to real life themes, such as The Little Red Chairs or Girl, show somebody steadfast in the obligation of a writer to tell the story of those who have no voice, since "otherwise she would be feeling she was betraying her trade since the writer must consider the worrying side of the world" (qtd. in Horgan). From the interviews for the New Yorker or $B B C 4$ we find out that she has also been enjoying a hermit-like life in a decadent apartment and on a tight budget. She says that "as a writer she lives a fairly secluded life [...] otherwise she cannot concentrate" (qtd. in Horgan).

O'Brien has been afraid of being publicly mangled ever since she sparred with the Irish reality of the mid- $20^{\text {th }}$ century after the publication of her first novel. She has already manifested her opinion that societyspoiled writers dried up their genius very quickly and that she needed to secure her integrity by not revealing her "inner gift and inner demon" (qtd. in Horgan). According to O'Brien, while continuously exerting pressure on writers, society has a role to play in safeguarding the selfimposed austerity that is the result of the chase after the public persona:

That thing of treating the writer like a famous boxer or a rock star has harmed writers, because one of the ingredients most essential for writing is that you have to be solitary. You can't be gregarious. You can't do both. The brain won't take it. That is why poor Mrs Woolf went off her rocker. Too many people, too much outside life. (qtd. in Moreton)

Visibility and invisibility have always been the binary concepts according to which the reading public saw O'Brien and her work, magnifying her faults and diminishing her victories. She was the stranger whom people admired and envied, fostering a titillating fear of identification. The 
private and public duality served for a long time as a repository for the misogyny directed at O'Brien, having in no way diminished in recent years. She has always lived in the limelight, and her existence has been one that easily becomes a timeless narrative. What ageing has supplied O'Brien with is her liberation from the gendered skin that has not resonated with the role she has always felt important, i.e., to voice the untold narratives of women.

O'Brien made her official public appearance with the publication of her controversial The Country Girls (1960) when Ireland was not ready to embrace a myriad of social debates and political campaigns, especially those dealing with the past, the Church and gender parity. Many deeply divisive questions continued to trouble the Irish nation during the period when O'Brien was in exile. At the same time, new literary and artistic forms gained importance, such as the contemporary visual and performative arts, as well as life-writing and autobiography.

During the period of feminist upheaval in Ireland and postfeminism in the United States, American writer Ursula Le Guin was writing about the gender differences during a newly delineated and culturally productive category of older people, mainly the post-climacteric woman. In response to the previous millennium coming to a close, she was touching upon the relationship between an author's gender and form. Women, for Le Guin, were more in synchrony with life. Women were living longer and more peaceful lives than men because of men's rampant and aggressive masculinity leading to a greater mortality rate. The distinction found its reflection in fiction:

Ernest Hemingway would have died rather than get old. And he did. $\mathrm{He}$ shot himself. A short sentence. Anything rather than a long sentence, a life sentence. Death sentences are short and very, very manly. Life sentences aren't. They go on and on, all full of syntax and qualifying clauses and confusing references and getting old. And that brings up the real proof of what a mess I have made of being a man: I am not even young. Just about the time they finally started inventing women, I started getting old. And I went right on doing it. Shamelessly. I have allowed myself to get old and haven't done one single thing about it, with a gun or anything. (Le Guin) 
For O'Brien, exiled in London, the need to write in defence of "girls" and to unveil the conditions of their exclusion came early in life and has continued until very recently with her publication of Girl: A Novel in 2019. On the other hand, O'Brien never considered herself a feminist as she struggled with the years-long reality of misunderstandings and misinterpretations between herself and other women. She believed that women were clearly responsible for the demise of the feminist cause while male writers went on building their success and were sustained by the opposite gender. This was also true, in O'Brien's opinion, of literary criticism, where the pattern of inequality prevailed: "Women, when reviewing, are more partial to male writers. I see them at parties, they gush over them - it's cultural orgasm. Women writers don't have quite the same cachet" (qtd. in Moreton).

Irish and British feminists found it difficult to sympathize with O'Brien because at that time there was no "culturally different feminist politics" (Pelan, “Edna O’Brien's 'Stage-Irish' Persona” 73) and because O'Brien herself would not commit herself to the feminist agenda. As a woman, above all, she did not have much choice like the majority of Irish women struggling to keep their poorly paid work in the world run by men. The law, the financial inequality, the glass ceilings were more than evident even at the beginning of the $21^{\text {st }}$ century. A clear example can be found in O'Brien's marriage to Ernest Gébler, a successful and profeminist writer in his early career, that ended up being a life-long nightmare. Coinciding with her coming of age as a writer and on publication of The Country Girls, there were many speculations whether it was Gébler who authored the first two novels as he would claim: "And jealous he was, according to their son Carlo Gébler, to an extent that his competitiveness with O'Brien [the 'Irish Colette' as he would call her] stultified his own career" (Woods 57).

That Ernest was bitter and resentful in response to O'Brien carving a well-deserved place in the Irish canon became clear quickly. Their marriage turned out to be one of abuse and violence, and soon O'Brien lost the custody of her two sons, Carlo and Sasha. The recent publication of Father and I: A Memoir by Carlo Gébler - an account of his father's life - shows a man eaten up by violent misogyny. The events were found 
in Ernest's diaries, and the notes he made for his own unwritten autobiography confirm that he actively denied O'Brien any agency and voice of her own, that is to say, any access to speech and social existence. What Gébler wrote of August Is a Wicked Month is a proof of the resentment he felt towards his wife's success:

There seems to be no-thing left in her slobbering mind to write about. Rather than give up she is ready to debase and befoul herself in public. The picture is as horrifying as a moronic woman screeching for attention in a market place and failing to get attention, raising her skirts and exhibiting her diseased sexual quarters. The raging vanity is turning into raging rage. (121)

The tragic events in her life led O'Brien to be rather cautious about people's intentions and to express somewhat extreme opinions of gender parity. Speaking about women's vote, she said, "the vote means nothing to women. We should be armed" (Country Girl 56). The dissolution of the symbolic patriarchal identity was not sufficient. As Whitford points out, "[i]dentity can be illusory [...] but men are still speaking and speaking for and in place of women" (137). O'Brien let her performance of gender develop "through a stylized repetition of acts [...] instituted through the stylization of the body" (Butler 402). This body "must be understood as the mundane way in which bodily gestures, movements, and enactments of various kinds constitute the illusion of abiding gendered self' (Butler 402). During her career and while living in exile, O'Brien was often criticized for being frivolous, indecent and writing lowbrow fiction, naturally only appealing to women. She was also believed to share other imputations apparently common to the female gender at large: she was sentimental and materialistic. Her loneliness and yearning for pleasure were often proved with what she lyrically puts it, "I was lonely. Cut off from the dance of life" (O'Brien, Country Girl 25).

The reading public saw her as producing excessively, publishing far too frequently and behaving like a female dandy. Yet she remained uninhibited and spoke openly about female sexuality and jouissance, something originally ascribed to men only. O'Brien wrote about that which in her opinion defined male/ female relationships: sexuality, infidelity, violence and emotional dependence. We can look at the 
example of "Mrs. Reinhardt", a short story included in a collection entitled Mrs. Reinhardt and Other Stories, published by Weidenfeld and Nicolson in 1978. The eponymous Mrs. Reinhardt ventures on a trip to France, driving through the paradisiac landscapes in order to escape her life at home. She is leaving her unfaithful husband who falls in love with a much younger woman and decides to abandon the marital home. While driving through the fields, she is watched by a semi-naked painter with an easel in his hand, who is interested in painting Mrs. Reinhardt's portrait. The narrator introduces the theme of a portrait of a young woman, now an older artist, because Mrs. Reinhardt had had her portrait painted when she turned thirty at the fancy of another man, her husband.

Apart from the negative feelings of despair and sadness, Mrs. Reinhardt is also experiencing an overwhelming enchantment with freedom, while the nature surrounding her nourishes the emotional deprivation she has experienced throughout her life. Mrs. Reinhardt catches glimpses of cows grazing, their udders heavy with milk symbolizing sustenance and abundance. There are a bakery and a clock on Mrs. Reinhardt's way, signalling further opulence and time, and she is given special care upon her arrival at the hotel whose chalets offer privacy for the plot to unravel. The clock reinforces the element of temporality and subtly informs us that we are dealing with a Reifungsroman in which identities of ageing women can now be reconfigured. However, through movement forward, Mrs. Reinhardt experiences flashbacks of her home life: the shame and despair she felt at finding out she had been put aside by her husband in favour of a much younger person. Travelling forward, her narrative is punctuated by sudden outbursts of past moments of overwhelming nostalgia for the past life. She cried for the shame her husband brought upon himself, she cried for her lost life, and above all,

She was also crying about age, about two grey ribs in her pubic hair, crying for not having tried harder on certain occasions as when $\mathrm{Mr}$. Reinhardt came home expecting excitement or repose and getting instead a typical story about the non-arrival of the gas man. (Mrs. Reinhardt and Other 213) 
It is O'Brien's choice to make the reader believe that Mrs. Reinhardt's life has been overshadowed by intrusive domesticity, madness and male infidelity. However, the short story is also about jouissance being absent from Mr. and Mrs. Reinhardt's lives; the well-being that does not necessarily disappear with age but with neglect. If we give in to the "whirl of domesticity" (Mrs. Reinhardt and Other 213), we no longer can feel delirious and "Happy, but Happy" (213). It is also true, as O'Brien notices, that men are quicker to find this lost happiness because of the freedom their gender has granted them. But the postmenopausal women are as likely to encounter solace and vital force in liberty of ageing since, "[t]he climacteric marks the end of apologising. The chrysalis of conditioning has once for all to break and the female woman finally to emerge" (Greer, The Change). There is an extra enchantment in solitude that opens Mrs. Reinhardt onto other people, most of them male admirers, and so, just like the female lobster she watches in a water tank and whom she names the Japanese Lady, she is roused and elated: "She had seen instinct, she had seen the grope and she had seen the will that refuses to be refused. She had seen tenderness" (O'Brien, Mrs. Reinhardt and Other 216). But since Mrs. Reinhardt's journey is a two-way process, her mind easily slips back into moments of self-denial: "If only I could turn the key on it and close the door and come back when I am an old woman. If only I could do that" (218). And so, when she meets "a man in his mid-twenties in a blue shirt" (220) and becomes infatuated by his stories, she looks "at her tiny wrist-watch" with "insect like hands" (223). Whether we misread the insect as incest is of less relevance, but we do realize that Mrs. Reinhardt is in jeopardy. The young man she encounters holds "the lighter in front of her face to admire her, to admire the eyes, the long nose, the sensual mouth, the necklace" (223), the very same necklace she kept after leaving her husband and which had belonged to his mother.

In her aptness and readiness to overcome age and emotional death, she admits that she "had read of women as she, who took up with men, younger men or older men, only to be robbed, stripped of their possessions, bled" (223). Yet her thirst for the real and the savage is still to be quenched through a series of unexpected events. "This fecundity of nature, this chorus of birds and the distant cooing of the doves" 
excite her desire because she is "recovering her pride as a woman, and much as a desirable woman" (227). When Mrs. Reinhardt's lover becomes abusive and is expelled from the hotel by its owner, Mrs. Reinhardt soon realizes that the necklace had been stolen from under her bed. She shivers at the thought of having her past foundations crumble. For a moment she finds herself on her own again, solitude necessary for the plot to take another turn: "Mrs. Reinhardt experienced one of those spells that can unsettle one forever. The world became black. A blackness permeated her heart" (235). Eventually, the necklace is recovered, and Mrs. Reinhardt settles into her usual self.

Out of the whirl of unexpected events, she receives a visit that culminates the short story. Alerted by the hotel owners and propelled by his own sense of guilt, Mr. Reinhardt appears on the doorstep. His visit is somewhat necessary in the convention that O'Brien has chosen for herself. The sinful and lost woman finds herself rescued by her steadfast husband whose infidelity is an insignificant attribute compared to his wife's madness. We find that nature is again attuned to the emotional weather, although the effect seems like an exaggeration. The naivety is reinforced by the dramatization of the situation in which "windowpanes seem to shiver" (239), the "dogs begin to howl" (239) and losing Mr. Reinhardt again would be "catastrophic" (239). As harmless and ignorant as this may seem, the power relation between Mrs. and Mr. Reinhardt is re-established, and the wife is warned to enquire no further: "One reaches out to the face that is opposite" because "who knows anything anyhow" (239). There is no autonomy in accepting the standards, but there is agency in admitting that certain pleasures in life can remain good even if momentary for both men and women. And the plot, although set in the last century, remains valid for readers nowadays, not so much showing them human nature but insisting on its failure to improve. O'Brien did not show her reservations and fragility shattering the standardized mixture of female obedience and devotion owing to which she was not considered a representative of Irish femininity. A flaneuse concealing behind her womanliness, O'Brien admitted, "I wanted to write and hope to write with vigour, with muscle. I don't care whether I am a man or a woman; I want 
to write as an androgynous person for whom language is sacred" (Country Girl 31).

Sharing in what looked like the Freudian propulsion to live, O'Brien instinctively craved life and life's pleasures, which led her to taking $L S D$ with AD Lang and to throwing parties with celebrities such as Paul McCartney. Angela Carter called O'Brien "a woman writer who pretends to be a female impersonator" (qtd. in O'Connor, "Edna O'Brien, Irish Dandy" 39), engaged in a masquerade of femininity performing her own womanliness publicly. O'Brien never gave up the idea that her voice must remain unchanged with time and that she must go on writing and defending "girls," a word that rarely disappears from the front covers of her novels. It has not only been with her memoir Country Girl that O'Brien returned to the issues of abuse. The themes of terror and violence can also be found throughout her entire oeuvre, including her recent novels The Little Red Chairs and Girl. Bittersweet depictions of relationships based on inequality between men and women, inaptness, women as circulating goods and unfulfilled desires have always characterised her fiction. The disparity she describes is visible in many public and private discourses and are amplified at the onset of puberty when women become objects of public/ male desire and their bodies assume the form of commodities for male gratification. Women are always depicted in relation to somebody because from the start they are seen as lacking, a scarcity that can be compensated with marriage,

Three women I know, married to very well-known writers, have said the identical phrase to me: 'I am married to one of the greatest writers in the world'. Well, fine. But if I had a husband, I don't think he'd be saying, 'I'm married to one of the greatest writers in the world'. I don't think he'd be really all that chuffed about it. (Country Girl 33)

Perhaps Simone de Beauvoir was right to write about ageing in her Coming of Age that the old "retain the virtues and the faults of the men they were and still are," a fact that the public considers an uncomfortable taboo (3). What is permitted at a younger age is usually not adequate for older people, be it the dress code, the manner of speaking or interests because older people are "policed and disciplined in distinctive ways" 
(Twigg 59). Furthermore, the ageing men and women are not entitled to any manifestation of desire because then they are looked at with disgust and repulse. Having established some of the boundaries of male and female sexuality, society finds it difficult to accept desire in the third- and fourth age, even with the prospect of increased longevity. It may be said that cultural and literary geriatrics has become a new challenge but also a solution.

O'Brien has refused to age on paper in her fictional writing, and her mind remains ageless like a flickering flame that gives off the same amount of light and warmth as it used to. At the age of 87 , she is still actively publishing and researching for her potential new novel so that she will not follow into the footsteps of other writers who stopped writing fiction after entering the third-age stage. David Malouf announced he would not be writing again at the age of 80 , and Alice Munro had spent ten years announcing the end of her writing career, having published her last novel in her seventies. Although O'Brien's The Little Red Chairs has been called a masterpiece and her most recent novel Girl will most likely be made into a film, her fiction shows some signs of deterioration: wavering narrative, frequent oscillation between the first- and third-person narratives, intrusion of pointless detail and unjustified use of extreme literary devices such as tragedy or death. Growing older is a matter of readjustment and not a foregoing of the voice or the disappearance of the body. Penelope Lively writes that she is "no longer aspirational" (217), but then she excuses herself by saying that the disenchantment with work "is not quite true. I do aspire in terms of wanting to do what I do as well as possible. I would still like to write a good book" (217). Ageing does not stand for letting go of life but reducing the acquisitive and competitive component of it. It can be managed in a tempered mode and still experienced with the freshness of a child:

Certain desires and drives have gone. But what remains is response $[\ldots]$ and a sea-change $[\ldots]$ a metamorphosis of the sensibilities, a gratitude for still being alive. Emotions are heightened; life resonates through the present simple pleasures and past complex memories. One becomes like a child welcoming life with a great intensity [...] it is like a lull. (Lively 209) 
Nowadays, O'Brien can be like the Phoenix that rises from the ashes many times against its fate of slander and resentment. In fact, until very recently, the public were willing to place a hatchet in O'Brien's head because of a misapprehension of a long-standing Irish tradition of the staging of the self that has existed for the sake of either self-preservation or the social critique (O'Connor, "An Astonishing Hatchet Job"). For them O'Brien's crafting of a public persona was nothing but a mellifluous hoax.

It is easy to believe that there is a reading public that anxiously awaits O'Brien's resignation, but this is unlikely to happen since O'Brien has always refused to change. Her own confession about hearing loss and subsequent refusal to use any hearing aid is a living example of her steadfast attitude and acquired stubbornness. What we see is a yoking of the intellect and the body through the physical existence into bodiless narrative nirvana: not merely a disassociation between the psyche and soma, but a merging of the two in the process of synthesizing an ageless voice.

The concept of a dichotomous identity is not uncommon for women authors and contributes significantly to dissatisfactions and misconceptions in relation to all bodies: ageing, aged and disabled. The recent rise of life writing and the theoretical lens of Reifungsroman foster understanding of the narratives of those whose self-awareness is in conflict with the normative cultural, political or economic discourses. The apparently trivial component of the other's gaze can be an obstacle to well-being. Behaviour, self-compassion, even the capacity of adjustment can be affected by the systemic discrimination towards women. Many facets need to be taken into consideration to change this situation; yet, above all, space and time is needed by those who want to speak. Individuals build their identity through communicative interactions because identity is a dynamic concept. The interactive nature of identity carries with it a variety of elements and voices that all need to be heard and accepted. There is no one way of performing gender and there is no one way of living ageing. Communication can only be safeguarded if there is no bias, no self-centricity and no violence that limit or supersede the individual freedom. 
What is inherent in O'Brien's narratives is her questioning of the normative discourse on ageing and thus refusal to age even when the visible signs of this process take their toll. Tracing the patterns in O'Brien's work and life makes visible a continuous and uncompromising transgression of the type which the society considers the standard. Her fictional voice, that has remained unaltered for many decades, teaches us a lot not only about human nature and relationships between people, but it also unveils our own character. O'Brien has preserved "a strong sense of self-worth to persevere over the course of her public and private trials" (O'Connor, "An Astonishing Hatchet Job") and she still provokes outcries of criticism as she continues to transgress, hoping that age will be her avenue to freedom eventually. For these reasons, readers have forever been divided between rejection and acceptance of O'Brien as an unruly woman who delineates the social and literary boundaries of a country; she can circulate and perform her own, now ageing, femininity even if this means the constant intrusion of the body.

As mentioned above, O'Brien has been irreversibly bound with her physical appearance at least until the 1990s, when her fiction took a more political turn. Until almost the dawn of the $21^{\text {st }}$ century her looks continued to reiterate her natural singularity and were often misinterpreted for a lack of agenda. Reflecting the passage of time, she has been both a woman author and a myth, embracing her femininity and the role of a female sage that Irish women writers lacked and longed for. That, as well as her playfulness, gave her the possibility to transgress the boundaries of correctness and of taboo. Everything that O'Brien did had the appearance of a play staged at the Abbey Theatre: genuine or not, everything about O'Brien was subject to public appreciation. Although she toyed with the idea of there not being a boundary between the public and the private, the breach between the lived experience and the unreal narrative was wide. Clearly, there is no doubt that O'Brien partook in some of the adventures she describes in her memoir, and yet, the spectacle seems to have had a very specific objective. What she craved was to uncover the uncensored voice and challenge the boundaries between the categories of gender, class and age. 
There is no threshold O'Brien did not overstep and there is no border she did not trespass. Patricia Coughlan writes in one of her studies that O'Brien's fiction is a proof of the ideological operations of traditional discourses in Ireland: 'O'Brien's work can be productively understood [...] in relation to Irish ideologies from the 1960's to the 1990's. [...] It confirms the existence and plays out the specific operations of Irish social exclusions and prohibitions" (180). For O'Brien, there has always remained the bitter feeling of disillusionment with the public at large:

After all this time, do prizes mean much? I think they do. One is only human. It is nice to be appreciated. I actually have not been the winner of many prizes. Never a Booker, never a Costa. Don't know why. Naturally, I am aware of it. I may have difficulty getting up and down steps but I am aware of everything. (qtd. in Moreton)

However, O'Brien's visibility has intensified in recent years, particularly after her winning the prestigious Frank O'Connor Short Story Award in 2011 for her collection of short-stories Saints and Sinners. That year, at the age of eighty-five, she admitted that she "had to get old. I had to have my hip surgery before they would give me the credit" (qtd. in Moreton). Many critics have started defending O'Brien, and academics have started giving her the deserved attention. Furthermore, O'Brien says that the new generation of reviewers does not sway under the baggage of the past as they see her as a story, a beacon for the future generations and at the same time a living testimony to the past.

There certainly exists a double standard in reading women's fiction as opposed to reading men's fiction. O'Brien has forever been on the steep slope from the canon to total dismissal because much of the public gaze has seen little in her stories besides sentimentalism. O'Brien has never been expected to write great and experimental fiction, and yet, looking back at her life story, one realizes that this is exactly what she has done. She has embraced the fight against complacency through her writing and through the liberty she self-imposed on her image.

In a 2011 interview in The Guardian, O'Brien was described as free from the fingers of time: "I cannot speak for custom, and its effect on her variety, but I will say this for Edna O'Brien: age cannot wither her" 
(Cooke). But there has been a new, more quiet and intimate side to O'Brien, as she admits: "It's becoming increasingly clear to me that the country of the mind is what is important" (qtd. in Horgan). It is the fact that O'Brien has almost become a fictional character of her own discourse that yields for a silent withdrawal, as she wishes to preserve the soul for herself. She might have found an ally in age because it leaves her "free to do what a novelist does anyway, listen and watch" (Lively 16). It confers a kind of "comfortable anonymity" (15). This is where Lively agrees that age is a bestowal of neutrality: "you are no longer out there in the thick of things, but able to stand back, observe, consider" (16), and Eílís Ní Dhuibhne has said during the launch of her most recent collection of short stories, Little Red: "One's voice as a writer gets stronger, more distinct as one matures, or ages" (Ní Dhuibhne).

O'Brien's writing seems to be withstanding the test of time so that she is not merely an observant flaneur but a pillar of Irish fiction. O'Brien has now become a literary reference and an embodied legend, a living legacy from which one can recover and stitch together the fragmented memories, symbols, and, above all, the universal narrative of "the girl," an archetype of oppression O'Brien finds in every tradition. She is reclaiming what has been burned on the book-burning pyres in Ireland. Having been 'othered' by society at large and having allowed herself to be the 'other' through acts of queering her own identity, O'Brien foregrounds her un-gendered, un-aged self, resistant to any cultural or political influence. Age has the power to erase all that, and, wherever the new light is shed, the public gaze disappears because "the possibility of women's difference" (Whitford 137) must enter the (de)constructive imagination to heal the fragmentation and dissemination. Without this creative approach, a woman will continue to be defined from the point of view of a man and in relation to him. The new ageing can flourish through repetition, "acts instituted through the stylization of the body and, hence must be understood as the mundane way in which bodily gestures, movements and enactments constitute the illusion of abiding [...] self" (Butler 402). 


\section{Works Cited}

Beauvoir, Simone de. The Coming of Age. New York: Norton, 1996.

Butler, Judith. Bodies that Matter. New York: Routledge, 1993.

Cooke, Rachel. "Edna O'Brien: A Writer's Imaginative Life, Commences in Childhood." The Guardian 6 Feb.2011. Web. 11 Dec. 2020.

Coughlan, Patricia. "Killing the Bats: O'Brien, Abjection, and the Question of Agency." Edna O’Brien: New Critical Perspectives. Ed. Kathryn Laing, Sinead Mooney, and Maureen O'Connor. Dublin: Carysfort P, 2006.

Duncan, Dawn. "Edna O'Brien and Virginia." The Canadian Journal of Irish Studies: Special Edition on Edna O'Brien (1999): 99-106.

Gébler, Carlo. Father and I: A Memoir. New York: Boyars, 2001.

Greer, Germaine. The Female Eunuch. New York: Harper Perennial, 2008.

---. The Change: Women, Ageing and the Menopause. New York: Ballantine, 1993. Kindle.

Heaney, Seamus. "Ireland's Final Frontier." The Independent 12 Sept.1995: 2-3.

Horgan, John. “An Irishman's Diary on Edna O'Brien and Fiery Critics: A Meeting to Remember." The Irish Times 16 Nov. 2015. Web. 13 Nov. 2020.

Le Guin, Ursula. "Ursula Le Guin on Being a Man." Brainpickings. 2014. Web. 13 Nov. 2020.

Lively, Penelope. Ammonites and Leaping Fish: A Life in Time. London: Fig Tree, 2013.

Moreton, Cole. "Edna O'Brien: I Had to Grow Old Before They'd Give Me Credit." The Independent5 Oct. 2014. Web. 13 Nov.2020.

Murray, Jenni. "Edna O’Brien, Christmas Traditions, Women in Law, Joanna Scanlan.” Women's Hour. BBC Radio 4 (7 Jan.2015). Web. 8 Nov.2020.

Ní Dhuibhne, Eílís. "Conversation with Eílís Ní Dhuibhne." YouTube, uploaded by Boston College Libraries. 2020. Web. 28 Oct.2020.

O’Brien, Edna. The Country Girls. 1960. London: Phoenix, 2007.

---. Mrs. Reinhardt and Other Stories. London: Weidenfeld, 1978.

---. August Is a Wicked Month. London: Penguin, 1986.

---. House of Splendid Isolation. London: Weidenfeld, 1994.

---. Down by the River. London: Weidenfeld, 1996.

---. Country Girl: A Memoir. London: Faber, 2012.

---. The Little Red Chairs. New York: Back Bay, 2016.

---. Girl. London: Faber, 2019.

O'Connor, Maureen. "Edna O'Brien, Irish Dandy." Edna O'Brien: New Critical Perspectives. Ed. Kathryn Laing and Sineád Mooney. Dublin: Carysfort P, 2006.

---. “An Astonishing Hatchet Job on Edna O'Brien: A New Yorker Writer is Taken to Task for His Mauling of Ireland's Greatest Living Writer." The Irish Times 16 Apr. 2020. Web. 11 Dec. 2020.

Pattison, Claudia. “Edna's Stock-in-Trade.” Western Mail 25 Apr. 1994: 8.

Pelan, Rebecca. “Edna O'Brien's 'Stage-Irish' Persona: An 'Act' of Resistance." The Canadian Journal of Irish Studies 19.1 (1993): 67-78.

---. "Reflections on a Connemara Dietrich." Edna O'Brien: New Critical 
Perspectives. Ed. Kathryn Laing and Sineád Mooney. Dublin: Carysfort P, 2006.

Tappe, Horst. "Edna O’Brien.” 1970. Photograph. National Portrait Gallery. Web. 10 Nov. 2020.

Twigg, Julia. "Dress and Age: The Intersection of Life and Work." International Journal of Ageing and Later Life 10.1 (2015): 55-67.

Whitford, Margaret. The Irigaray Reader. Oxford: Blackwell, 1991.

Woods, Michelle. "Red, Un-Read, and Edna: Ernest Gébler and Edna O’Brien." Edna O’Brien: New Critical Perspectives. Ed. Kathryn Laing and Sineád Mooney. Dublin: Carysfort P, 2006. 